\title{
Study and remediation of environmental problems caused due to the growth of algae in speleothems of calcareous caves adapted for tourism- a case of success in Spain
}

\author{
Rubén Esteban Pérez
}

\begin{abstract}
Esteban Pérez R. Study and remediation of environmental problems caused due to the growth of algae in speleothems of calcareous caves adapted for tourism- a case of success in Spain. J Environ Geol 2017;2(1): 20-27.

Caves, mainly those located on calcareous rocks are one of the best examples of geological heritage around the world. Their care and preservation should be a priority for the authorities dealing with the environment and culture. In addition to the dryness and discoloration wrought about by algae and bacteria in the speleothems, huge amounts of visitor traffic to the caves pose an additional burden, which is harmful to the conservation of the calcareous structures present inside the caves.
\end{abstract}

This article is a compendium of the results and the on-going studies under the Rehabilitation Project of Ortigosa de Cameros system caves. This project deals with the assessment and clean-up of exogenous algal communities that have deteriorated the speleothems

in the tourist caves located in the municipality of Ortigosa de Cameros
[Spain].In order to choose an appropriate cleaning agent for the speleothems, a bibliographic review was conducted. Several methods of remedying including the use of mechanical as well as chemical methods have been discussed.

After selecting the agent of choice for the clean-up of the speleothems, laboratory and in situ tests were performed using the same. Based on the results of these initial studies, the same methodology was applied to all areas affected by the "lampenflora". Care was taken that the selected methodology did not cause any damage to the fauna that inhabits these caves and nor did it leave a perceptible trace. An economical and environmental friendly method is still required to eliminate the algal mat that covers the speleothems of many caves adapted for tourist visits, in order to preserve our subterranean geological heritage throughout the world.

Key Words: Cave, Speleothem, Environment, Remediation, Lampenflora, clean-up, Heritage, Ortigosa
Science has shown that the areas around the artificial light spots installed in Stourism enabled caves, foster the growth of heterogeneous and exogenous plant communities in the biocenosis of the underground environment. These communities produce metabolites and aggressive chemical products which erode the rock formations of the caves.

The eradication of calcareous concretions has resulted in a wide variety of research work being carried out in some of the most important tourist caves in the world. In all of these studies, the first consideration is always given to the type of lights installed in the caves, in order to determine whether the removal of these lights is detrimental to the growth of these new plant species.

However, once it has been determined that the lighting system does not favor the growth of algae, the removal of the underground flora using mechanical processes or chemical products using a methodology tested for the caves, become a priority. While deciding on the agent or method, care is taken that there is no damage or to the speleothems or to the native organisms native to the ecosystem of the cave. Furthermore, it is also taken into account that the agent is imperceptible to the staff and visitors.

This article highlights the work carried out in the tourist cave system of Ortigosa de Cameros in the province of La Rioja [Spain], which is one of the best exponents of the Spanish underground geological heritage.

As observed in Figure 1, the area of the caves is mainly formed of predominantly Middle Jurassic calcareous materials, which can be described, based on the works of Colchen (1) and Ramírez Merino et al. (2), as rocks corresponding to the limestone of the Bajocian- Lower Callovian Age.

This limestone is of the mudstone type with oolites forming a "karstic modeling" that are the characteristic features of the geomorphology and subterranean hydrogeology in typical calcareous regions (3).

Also, the area presents an assortment of compact limestone banks well stratified and limited by discontinuities. Faults are located more or less perpendicular to the banks, with the predominant orientation being NE-
SO. Therefore, the faults turns this calcareous mass into a kind of piling of parallelepipeds that allow water to infiltrate easily and create a system of caves, while the compactness and coherence of the rock, due to its mineralogical composition, ensures the conservation of the caves (4).

It should be noted that karst models are eminently erosive (5). Although there are several processes that act on karst, dissolution is the dominant one. In addition to a relevant exokarst relief, the high pluviometry of this area [679 $\mathrm{mm}$ ] also favors the evolution of the karst and the formation of a system of galleries and chasms (6).

Calcareous soils develop on such terrains, and support a vegetal cover comprising of Quercus rotundifolia and Quercus ilex. Additionally, exokarst structures comprising mainly of channels and small dolines are also formed (7) (Figure 2).

It is also important take into account the dissolution of the rocks due to the effect of water. Local limestone has a great homogeneity in its mineralogical composition since it is formed almost exclusively by calcite, with indications of quartz and phyllosilicate (8). It is also important to know the threedimensional model of the karst since it is an underground modeling where there is no clear relationship between the endokarst and exokarst areas, as there is an apparent disconnection between some forms and others.

The system of caves appears horizontal and is characterized by a number of speleothems with good conservation for the most part, and with some current dynamics of growth. Inside the caves, the average annual temperature is $11.5^{\circ} \mathrm{C}$ and the atmosphere is saturated with water vapor. The dripping is maximum in autumn and minimum in spring, and it can even cease completely in summer and winter (7).

According to municipal data, these caves have a considerable tourist attendance, with around 20,000 visitors per year on average. These tourist visits are spread across the summer period, spring and autumn weekends, and Easter holidays.

For the very first time in Spain a study on these characteristics have been

Researcher Geologist, IER - Research Institute, Ministry of Economic Development and Innovation, Government of La Rioja, Logroño, Spain

Correspondence: Rubén Esteban Pérez, Researcher Geologist, IER - Research Institute, Ministry of Economic Development and Innovation, Government of La Rioja, Logroño, Spain. Telephone +34-941291185, +34-646579321, e-mail rubenep2900@icog.es

Received: March 26, 2018, Accepted: April 17, 2018, Published: April 27, 2018

open Access

This open-access article is distributed under the terms of the Creative Commons Attribution Non-Commercial License (CC BY-NC) (http:// creativecommons.org/licenses/by-nc/4.0/), which permits reuse, distribution and reproduction of the article, provided that the original work is properly cited and the reuse is restricted to noncommercial purposes. For commercial reuse, contact reprints@pulsus.com 


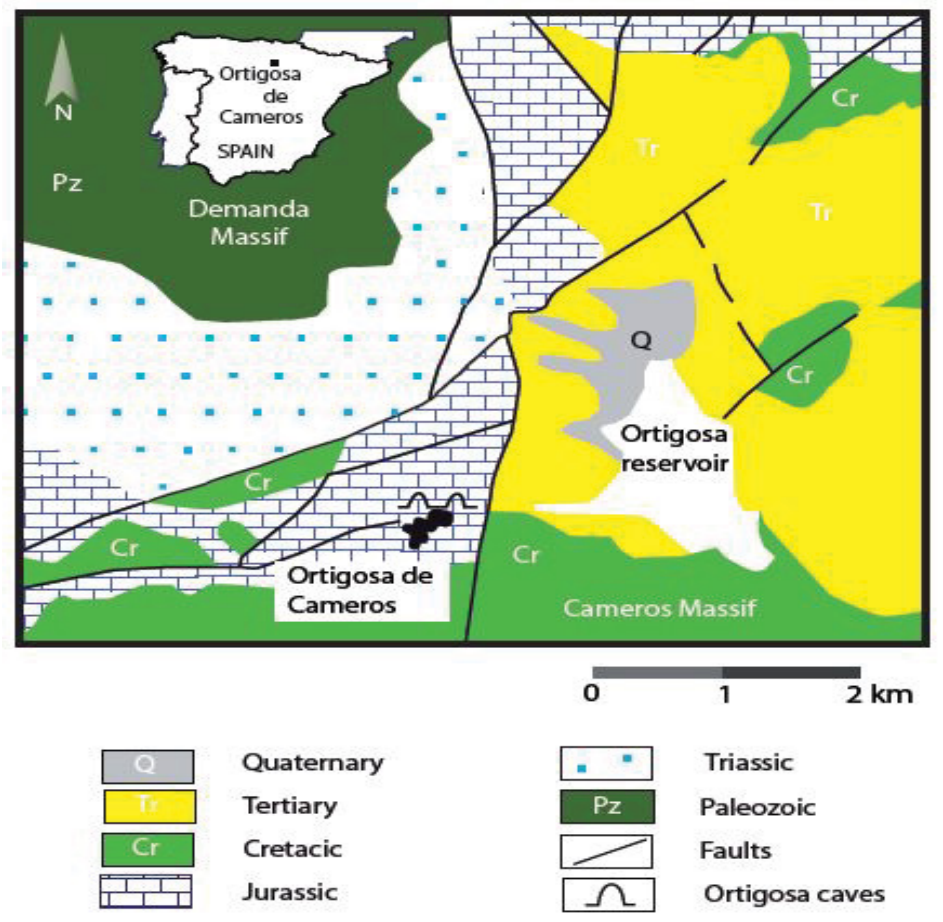

(*) Modified from Osácar et al. (2013)

Figure 1) Area of the caves mainly formed of predominantly Middle Jurassic calcareous materials

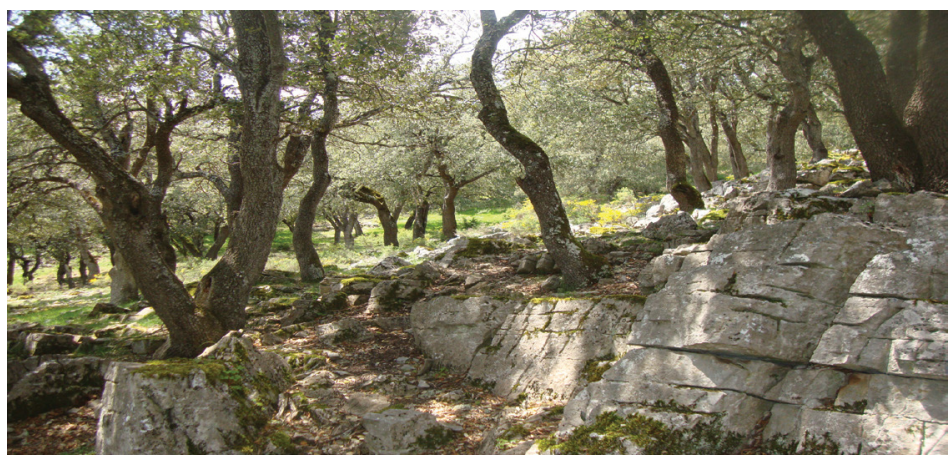

Figure 2) Exokarst relief of the study area

carried out as a part of construction project for the rehabilitation of tourist caves, and in few cases there are references, that have been carried out in caves throughout Europe. The references on which this work is based show us the history of this type of treatments in speleothems affected by climatic conditions modified by tourism. The use of applied science and technique in this work makes this study more important because as they both converge to improve the environmental conditions of a particular biotope, such as an underground cave system.

\section{METHODS}

Evaluation of the environmental problems of the caves

This underground system was discovered and explored in the $60 \mathrm{~s}$ of the $20^{\text {th }}$ century. Later it was adapted for tourist visits and an artificial entrance in the vault of one of the main caves was opened for the same [Gruta de La Paz] (Figure 3). Further, artificial lighting equipment consisting on incandescent light bulbs of yellow light were installed. These lasted until the end of the $90 \mathrm{~s}$.

The previous studies revealed a direct correlation between the increase in the number of visitors and rapid discoloration, dryness, deterioration by microorganisms. Colonization of the speleothems with plants was found to be directly related to the type of artificial lighting (9)

As for the discoloration and desiccation of the speleothems, it was maximum at the entrance of the two main caves [La Viña and La Paz]. The more important one being the artificial entrance of the Gruta de La Paz [south entrance].

Andrieux (10) had demonstrated that it was the variations of temperature, humidity and pressure of the outside air that activated the movements of the air in the underground system.

If we denote the masses of the volume of outside air and of the underground air, as $\mathrm{W}_{\text {ext }}$ and $\mathrm{W}_{\text {sub }}$, respectively, it follows that:

a) If $W_{\text {ext }}>W_{\text {sub }}$

Cave with one opening:

Floor $\rightarrow$ suction

Vault $\rightarrow$ blow [air injector]

Cave with several openings:

Low opening $\rightarrow$ suction

High opening $\rightarrow$ blow

b) if $W_{\text {ext }}<W_{\text {sub }}$

Cave with one opening:

Floor $\rightarrow$ blow

Vault $\rightarrow$ suction

Cave with several openings:

Low opening $\rightarrow$ blow

High opening $\rightarrow$ suction

c) if $\mathrm{W}_{\text {ext }}=\mathrm{W}_{\text {sub }}$ 


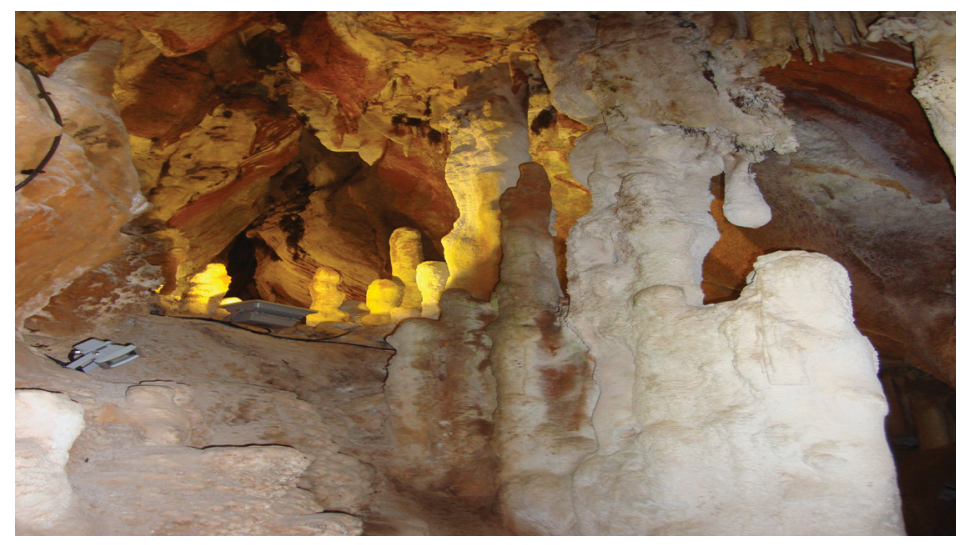

Figure 3) View from the south entrance of the Gruta de La Paz where the extreme dryness and discoloration of speleothems is observed

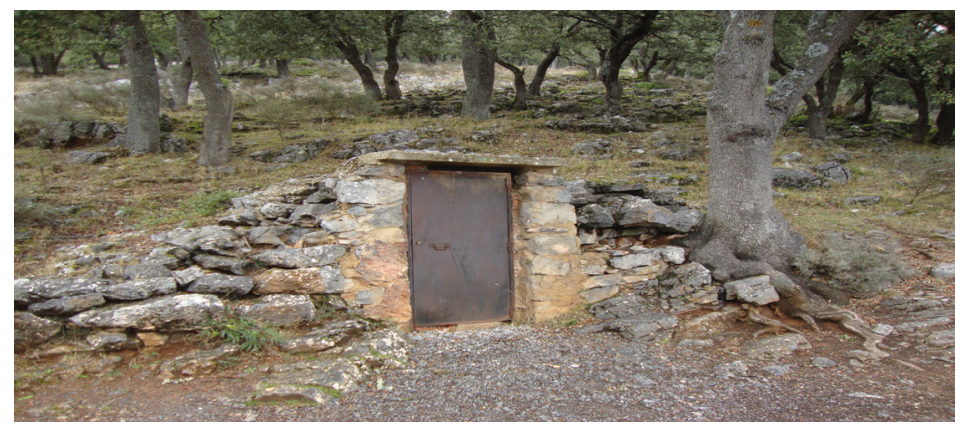

(a)

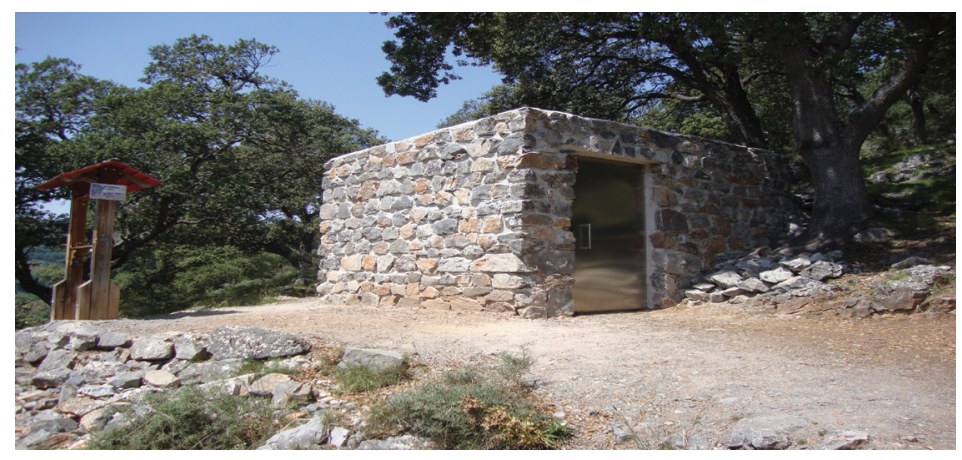

Figure 4) Old entrance door and new climate access camera

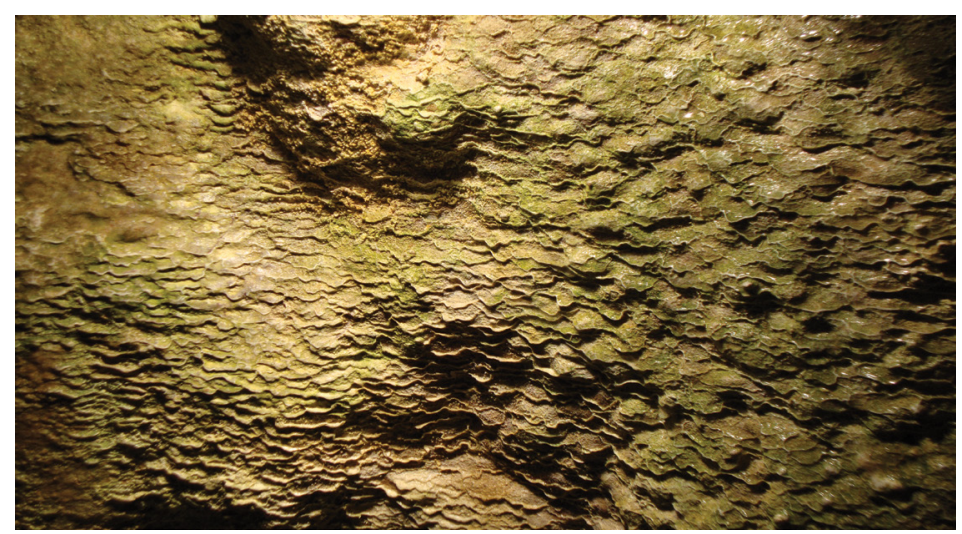

Figure 5) View of a speleothem affected by the moonmilk

These mechanisms have been observed in these caves according to the seasons:

a) During the cold season.

b) During the warm season.

c) During the interconnections [there are two in an annual cycle].

The displacement of the air masses is responsible for all the climatic changes

J Environ Geol Vol 2 No 1 April 2018 in the underground system. This displacement produces thermodynamic transformations so that heat can be transmitted in different ways depending on the heat of different areas in contact with the atmosphere (11).

In the case of the Gruta de La Viña which has a single entrance, a circulation called the "air bag" is present. The displacement of the air in such cases is dependent on the cavity being in each of its sections of ascending, horizontal or descending type and of the season. 
The Gruta de La Paz, however, has two entrances [the south one is artificial] located at approximately the same height with an air flow known as the "wind pipe"; this type of air flow has very low intensity.

The aeration regime in such caves is permanent, and is the flow of laminar or turbulent air depending on the relative roughness of the substrate on which it circulates.

In order to detect the different types of aeration regimes, the free ballast balloons method is used. If is the air flow follows a laminar regime, the movements are ordered and stratified and the balloons move parallel to each other. However, if the ventilation is turbulent, the balloons collide against each other and the walls.

The phenomena of evaporation and condensation are also seasonal. In the tourist caves, the effect of temperature variation and artificial lights on evaporation and condensation has not been observed as clearly as in nontourist caves where the walls are full of small drops of water or fog.

This air also has a higher percentage of water vapor due to the intrinsic characteristics of the limestone that makes the water maintain its relative humidity when it evaporates in the caves, favoring the dragging of $\mathrm{CO}_{2}$.

For these reasons, the effect of desiccation and discoloration is mainly visible in the area of the artificial entrance of the Gruta de La Paz. For more than 40 years, since its opening, the desiccation has been advancing towards the interior of the cave, reaching more than 50 meters in 2017 from this south entrance.

To help this process of humidification of the interior air of the cave, several drums containing 250 liters of water were placed in two points. This process helped in humidifying the air from the water coming from outside, as when the water vapor was transmitted to the air, the pressures were equalized. That is, the temperature of the air in the cave is higher than that of the water and therefore the evaporated water transmits the heat to the air. In the end, this leads to the balance between the received heat and the supplied heat. These drums were removed for purely aesthetic reasons in 1999.

In 1999, when the lighting system of this cave was being modified, the incandescent bulbs of yellow light were replaced with white light halogen bulbs [which also generate heat].

When the caves are closed to the public from November to March and the artificial lights go out, the system is considered thermally isolated. The temperature of the air drops until it is saturated with water vapor and condensation takes place in the areas closest to the entrance.

From the aforementioned facts, it follows that the existence of a system of air humidification contributes to the development of condensation, so the dryness of the speleothems can be counteracted in a remarkable way. The drums filled with water contributed to this effect, but their removal in 1999, was not followed-up with an alternate arrangement of a water source.

The variation of the physical characteristics of the aeration regime resulted in the construction of a climatic chamber at the entrance of the caves in 2014. This chamber replaced the old entrance door by a visitor reception area, which performs the additional function of equalizing the pressure and temperature inside the cave with that of the camera and prevents the generation of artificial air flows that modify the environment of the cave.

This system has had a positive effect on the improvement of evaporation and condensation inside the cave. However, it will be necessary to study the recession of the dryness and the return to the natural conditions of the cave, in the future (Figures 4A and 4B).

As for the vegetation, native and allochthonous flora and microorganisms can be found inside the caves; this flora has been found to be related to the visits of tourists.

The autochthonous flora of these caverns is usually comprised of organisms that have been accidentally dragged inland by the air flows, water or visitors. Somehow, this autochthonous flora managed to survive in the precarious conditions of the caves (12).

It is important to remember that according to the intensity of the natural light that enters a cave; four successive zones of plant growth can be found:

1) An entrance area where both phanerogams and cryptogams that need a minimum luminosity of at least $5 \%$ from the outside are found;

2) The vestibular area that contains mainly mosses and lichens with a luminosity of between 2 and $1 \%$;
3) The twilight zone with contains lichens and algae of luminosity lower than $2 \%$, and

4) The last zone or dark zone where the fungi and some algae live (13).

However, allochthonous flora has been observed in areas around the artificial lighting. This is due to the fact that the points of warm light inside around these lighting sources provide optimal luminosity and temperature for the growth of the plant. However, the central circle closest to the artificial point of light is devoid of any vegetation as a result of excessive heat.

The last environmental problem encountered in the caves, is the deterioration of the caves by microorganisms or "moonmilk" (Figure 5). These are nothing but bacteria associated with the alien algae that also destroy the speleothems. This process is partly natural and partly induced by the greater number of visitors and the growth of allochthonous algae inside the caves.

The visitors to the caves produce an effect of elimination of the autochthonous bacteria. The autochthonous bacteria, which have adapted to low levels of energy, are replaced by bacteria have adapted to take nourishment from the high energy levels obtained from the fibers of the clothes or the skin cells of the people who visit the caves.

Due to the higher relative humidity of the outside air in summer, the deposits of organic matter occur in the upper part of the walls; in winter, a lower relative humidity in the outside air leads to organic matter deposition in the lower part of the caves. Furthermore, in winter, when the air inside the cave is hot, the walls dry up, and in summer the cool air in the cave is more receptive to the organic matter.

The greatest corrosion of speleothems by microorganisms occurs, in the areas near the entrances of the caves. To prevent any further deterioration in the speleothem structure by the microorganisms in these areas, it is necessary to prevent the formation of any type of deposit of organic matter. For the same reason, visitors to the caves will be urged not to touch them.

The moonmilk absorbs a lot of water and becomes a soft and light paste that when dried becomes a powdery product of hard consistency and crumbles easily. It can be seen in several areas of the Gruta de La Paz. If the allochthonous subterranean microorganisms disappear, the formation of moonmilk will also stop.

Moonmilk is a difficult phenomenon to eradicate as visitors bring with them a large amount of microorganisms and fibers inside the caves.

Considering the above, problems pertaining to the growth of algal communities, known by the international scientific community as "green sickness" or "lampenflora", are considered the most harmful for the future conservation of calcareous structures of the caves.

According to Sánchez Castillo and Bolivar (14), there are several communities of algae (Cyanophyceae, Chlorophyceae and Bacilliariophyceae) that can cause surface deterioration and chromatic alteration in speleothems (Figure 6). In a first, we located different deterioration pathologies in the caves. Pustules formed in the initial stages of colonization. They have a hemispherical shape in variable sizes. In in most cases these pustules are small and are green or black in color and are associated with deterioration called "pitting".

Coatings, that are sufficiently homogeneous and thin, correspond to the phase of secondary development that is indicative of a great increase of the substratum coverage, without necessarily indicating an increase in the complexity of species and biotypes. These communities give rise to a patina of colors, and mats that are thick sheets which present filamentous species that are normally stratified (Figure 7).

Bibliographic research and test methods related to the allochtonous plants

The previous bibliographical reviews indicated a series of relevant points to evaluate in this work.

Newbould (15) developed methods both mechanical as well as chemical, to identify an adequate speleothem cleaning system. One of the examples used in some Australian tourist caves employed a mixture of biocidal chemicals with pressurized cold water injectors (16).

Knutson (17) and Johnson (18), posited that the mobilization of underground flora can be done using chlorine-based chemicals in small doses, as they do not cause damage to the speleothems or animals living in the caves. Therefore, for the definitive eradication of algae that grow in response to artificial lights, it is necessary to take into account the type of existing lights.

According to Caumartin (19) and Roth (20), the fight against algae should be 


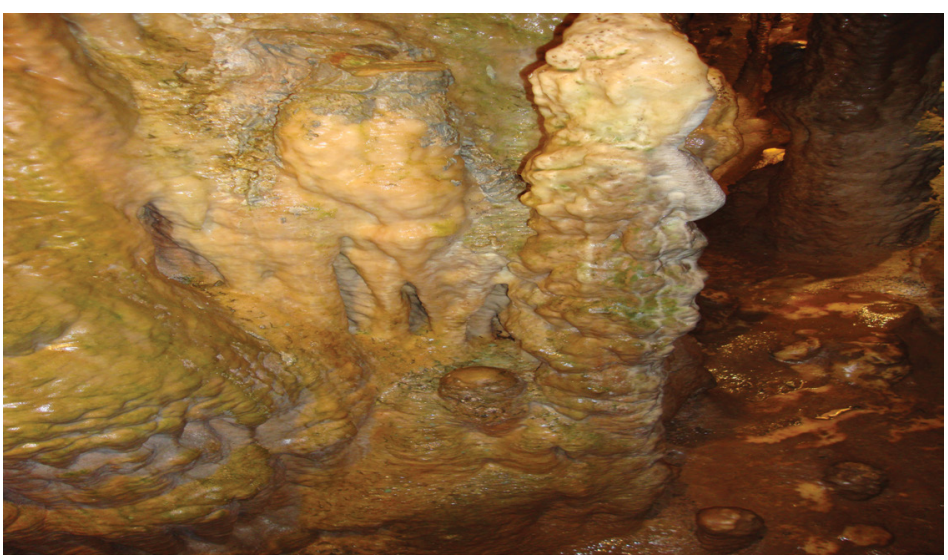

Figure 6) View of a speleothem covered with a coat of algae that completely cover the mineral substratum

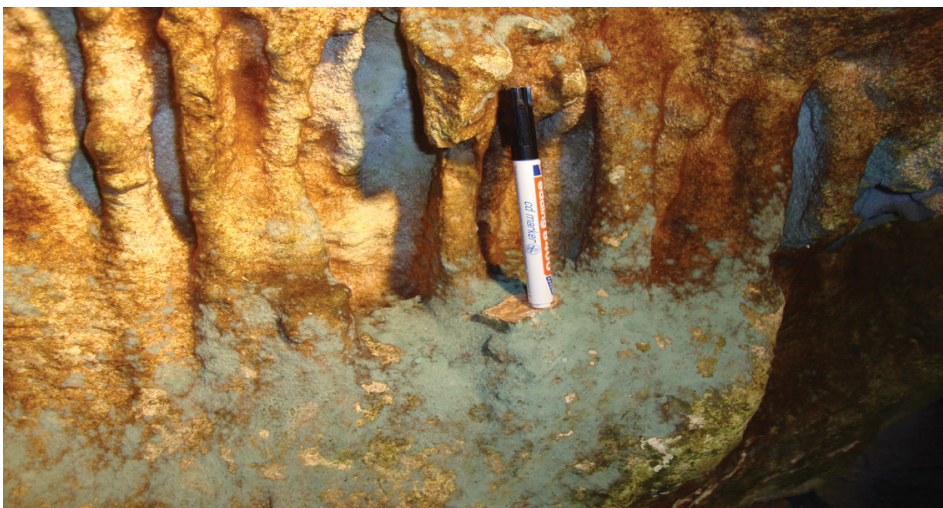

Figure 7) View of a mat with different types of algae that completely cover a mineral substratum

initiated by selecting electric lamps with emission spectra that are removed as far as possible from the absorption spectra of chlorophyll, and emit as little heat as possible. Plants capture different wavelengths in the white light and not all of them capture the same wavelengths. Mosses, fungi and green algae are known to capture the wavelengths in the range of 430 and $453 \mathrm{~nm}$, whereas blue, red and orange algae capture wavelengths in the range of 600 to $700 \mathrm{~nm}$. Wavelengths that are not absorbed by the chlorophyll containing plants would be in the range of 453 to $600 \mathrm{~nm}$. These facts also indicate that lamps with incandescent filaments should not be used. Further, the LED systems should offer high performance in cold light and adapt perfectly to the illumination of the underground caves.

Lemon (21) and Bonwick et al. (22), state that in addition to maintenance problems, the high number of visitors to tourist caverns creates a special type of pollution. Likewise, the possible existence of a direct relationship between the increase in the number of visitors and the progressive increase in discoloration and corrosion of the speleothems adds another dimension to our understanding $(23,24)$.

Faimon (25) suggested the use of hydrogen peroxide for controlling the underground flora, and stated that as compared to biocides or hypochlorites, this method is more respectful of the cave environment.

A study by Mulec (26) discussed the various methods proven to control the growth of algal communities in various European caves. This study concluded that as the climatic conditions are constantly changing in the tourist caves, there is no definitive method to eliminate the allochthonous flora that appears as a result of these changes.

A study by Cigna (27) investigated the problem of "green sickness" in underground caves. The study concluded that the use of herbicides is very harmful to the native fauna and native flora of the subterranean caves. The study suggested use of other methods, which are more respectful to the environment. Interestingly, this study recommended the use of LED lamps in caves visited by tourists.

A study by Hebelka (28) studied the effects of various treatments on the subterranean algal flora and concluded that the use of hypochlorites might be harmful to health and that it cannot definitively eliminate the allochthonous flora. This study argued that prevention of the growth of these algal communities is itself important. Finally, Esteban (29) carried out several such studies in these Spanish caves.
RESULTS

\section{Field visits and sampling}

The field studies identified the allochthonous plants in the speleothems of the Caves of Ortigosa de Cameros as:

\section{Green algae}

2. Blue algae

\section{Mosses}

4. Patterns of blackish color in stalactites [only in the Gruta de La Viña]

\section{Vascular plants}

As mosses and vascular plants grew in response to natural light at the entrance of the caves, they were identified as not being invasive and having no effect on the speleothems.

Black colorations detected in the Gruta de La Viña were identified to be the product of humic acid filtrations on the surface, in which occurred as a result of the metabolism of the holm oaks that grew in the area. Therefore, these black colorations were found to be a product of the natural evolution of the rocky substratum without any major problems [conclusions of the conversation with Prof. Arsenio Muñoz, University of Zaragoza].

The rest of the problem focused on algae both green and blue that grew in response to artificial light sources within the caves.

Samples of green and blue algae were collected from their rocky substratum. Six samples were prepared:

-Stalactite with black patina [Gruta de La Viña].

- Sample with moss [Gruta de La Paz]

- Sample with blue algae [Gruta de La Paz]

- Sample with green algae [Gruta de La Paz]

- Sample of patina with green algae and lichens [Gruta de La Paz]

- Sample with pisolites [Gruta de La Paz] 


\section{Previous tests and the selection of the cleaning method}

Based on the review of literature, the possibility of using two general types of treatment in order to eliminate the subterranean flora was evaluated:

1. Mechanical methods [brushing, sanding or grinding]

2. Chemical methods:

- Hypochlorites

- Peroxides

- Biocides

The use of any type of biocide was ruled out due to the negative effects on the endogenous fauna of the cave [especially the chiroptera] and towards the percolation water of the calcareous massif, which are very important in the rainy or snowy season and that emerge through several springs (30).

Mechanical methods were also ruled out, given the sensitivity of some of the existing speleothems [mainly helictites] to scratching or roughing when brushes were used to eliminate algae that had calcified in many speleothems.

Two types of hypochlorites, sodium and calcium were evaluated and tested in the laboratory. Both of these were discarded as Chlorine reduced the $\mathrm{pH}$ of the water and caused dissolution of $\mathrm{CaCO}_{3}$ from the speleothems tested. Chlorine could also pose as an undesirable biocidal effect for the subterranean fauna, leading to the generation of a reddish coloration in the calcite due to the oxidation of the $\mathrm{Fe}$ that precipitates as iron hydroxide $(\mathrm{FeOH})(31)$.

The probable generation of gas within the caves due to the use of chlorinebased products can have adverse effects on the fauna by the formation of chloramines that negatively influence the water and the subterranean environment (32).

Finally hydrogen peroxide was chosen (33). This method has been used in many tourist caves in Europe, and according to literature, it is more underground environment friendly and exhibits the best results after use.

We used a solution of $30 \%$ commercial hydrogen peroxide $\left(\mathrm{H}_{2} \mathrm{O}_{2}\right)$ diluted with distilled water as a base. For the treatment, two concentrations of $\mathrm{H}_{2} \mathrm{O}_{2}$ were prepared: $15 \%$ and $25 \%$, in order to avoid discoloration of the speleothems.

In order to avoid the puncture effect of $\mathrm{H}_{2} \mathrm{O}_{2}$ in the speleothems, the solutions were presaturated with the $\mathrm{CaCO}_{3}$ collected from the cave itself [pieces of limestone collected in the caves], fifteen hours prior to their use.

Taking into account that the oxidation properties in an alkaline medium of $\mathrm{H}_{2} \mathrm{O}_{2}$ are expressed by the following equation:

$\left(\mathrm{HO}^{-}\right) 2+\mathrm{H}_{2} \mathrm{O}+2 \mathrm{e}^{-}=3(-\mathrm{OH})$

It is noteworthy that the standard redox potential value- $\mathrm{EO}=0.88 \mathrm{~V}(34)$, indicates oxidation properties similar to those of hypochlorite.

Therefore, the oxidation process of hydrogen peroxide can be expressed by the following equation:

$\left(\mathrm{CH}_{2} \mathrm{O}\right) \mathrm{n}+2 \mathrm{n}\left(\mathrm{HO}^{-}\right) 2=\mathrm{nCO}_{2}+\mathrm{H}_{2} \mathrm{O}+\mathrm{n} 2 \mathrm{n}\left(\mathrm{OH}^{-}\right)$

In spite of being a very slow, this process was found to be agreeable with the environment. Further this method it did not acidify groundwater and it did not generate gases harmful to flora and fauna.

\section{Laboratory tests with the chosen methodology for cleaning}

The samples were tested with $15 \%, \mathrm{CaCo}_{3}$ presaturated $\mathrm{H}_{2} \mathrm{O}_{2}$. The samples were sprayed again with the solution, after six hours of treatment. The stalactites with humic acids were observed to be clean of the blue algae; and the stalactite and pisolite samples were found to be $75 \%$ of the green algae.

After three days of treatment, the stalactite samples with green algae were completely clean, but the calcareous samples with green algae still required further cleaning. For the clean-up of these calcareous samples, $25 \% \mathrm{H}_{2} \mathrm{O}_{2}$ was used. Four days after this treatment, the calcareous patina was completely clean.

To finish the clean-up, distilled water was sprayed under pressure to remove the excess chemical that remained attached to the samples.

However, $\mathrm{H}_{2} \mathrm{O}_{2}$ treatment was found to be not effective at removing moss, with only a slight discoloration being observed upon treatment. Nonetheless, this was not a problem as moss grew in these caves only in response to sunlight (Figures $8 \mathrm{~A}$ and $8 \mathrm{~B}$ ).

\section{Tests in situ}

After the laboratory tests were evaluated, In situ tests were initiated in localized and controlled areas in the caves. The Gruta de La Paz was chosen mainly for these tests given the greater proliferation of green and blue algae; four areas were chosen in this cave. One area was also selected for in situ testing in the Gruta de La Viña where stalactites with black patinas were observed.

The test areas chosen were:

- Calcareous rug with blue algae

- Stalactite with green algae

- Pisolite area with green and blue algae

- Calcareous stalagmite with green algae

-Area of stalactites blackened by humus [Gruta de La Viña]

At the time of performing the in situ tests, the average temperature of the caves was $12^{\circ} \mathrm{C}$ and the relative humidity was close to $100 \%$.

These tests began in January 2014, with the spraying of presaturated $\mathrm{H}_{2} \mathrm{O}_{2}$ in the selected areas. The treatment was repeated on two subsequent days separated by 2 weeks.

The rapid hydrolyzation of the solution was observed. As the effervescence of the product that in the laboratory tests lasted over time, in the "in situ" tests it ended in a few hours. It follows that this was due to the high relative humidity of the cave air. Despite this, the chemical process that takes place inside the cave was the same as that was conducted in the laboratory. The only difference was that, in the in situ experiments, there was a need to repeat the spraying operation over the speleothems more often.

The areas were washed with spring water before the impossibility of washing large areas with bottled distilled water. It is a water of low mineralization and most importantly, has no chlorination treatment.

After washing, it was remarkable that the blue algae disappeared entirely and green algae reduced by $60 \%$. Green algae in the pisolite areas were eliminated by $75 \%$. The blackened stalactites also whitened by $75 \%$.

Areas that had not become completely clean with the $15 \% \mathrm{H}_{2} \mathrm{O}_{2}$ solution were sprayed with $\mathrm{H}_{2} \mathrm{O}_{2}$ presaturated at $25 \%$. In 2 months, the cleaning of these areas was complete (Figures 9A and 9B)

\section{Cleaning works}

Cleaning work in the caves began in March 2014. The H2O2 solution was applied at $15 \%$ to all areas with algae [31 areas in the Gruta de La Paz and 11 areas in the Gruta de La Viña].

The solution was reapplied twice. All applications were carried out using a manual pressure pump to spread the spray or solution jet in all corners of the caves where the invasive algal communities had grown. A total of 175 liters of the solution were used.

After 1 month, spring water was sprayed in all areas previously treated with the $\mathrm{H}_{2} \mathrm{O}_{2}$ solution.

Some areas, especially areas with calcified green algae, were not completely cleaned by this process, so a $25 \% \mathrm{H}_{2} \mathrm{O}_{2}$ solution was applied to these points during April 2014.
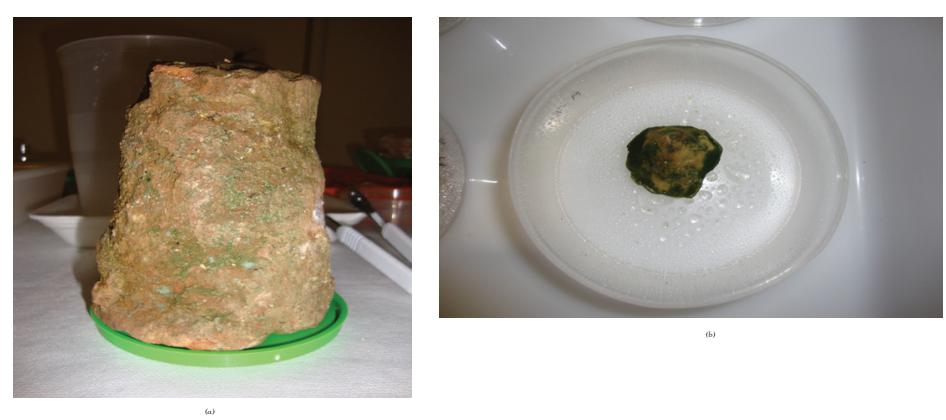

Figure 8) Laboratory tests performed on samples taken in the caves 
Cleaning was successfully carried out at all points where the calcification of the green algae had not taken place or was very superficial. In case of calcified green algae, the natural $\mathrm{CaCO}_{3}$ cover prevented the $25 \%$ solution of $\mathrm{H}_{2} \mathrm{O}_{2}$ from eliminating the algae community.

$\mathrm{H}_{2} \mathrm{O}_{2}$ was not used in higher concentrations as it is harmful to speleothems when groundwater is acidified. Furthermore, as it is a bleaching agent it can excessively discolor the calcareous structures on which it acts.

As previously explained, $\mathrm{H}_{2} \mathrm{O}_{2}$ pre-saturated with $\mathrm{CaCO}_{3}$ converts the peroxide into carbonic acid $\left[\mathrm{H}_{2} \mathrm{CO}_{3}\right]$ and, therefore, according to literature and laboratory tests, $\mathrm{H}_{2} \mathrm{O}_{2}$ concentrations greater than $25 \%$ negatively affects the speleothems by discoloring the calcium carbonate.

A more aggressive chemical process was not used, taking into consideration the safety of the fauna and the staff working inside the caves.

\section{Later revision}

In summer/autumn 2014, the caves of Gruta de La Paz were evaluated for the presence of efflorescence in speleothems. . No efflorescence was observed in majority of the underground system; however, some specific areas, did exhibit a white efflorescence was observed over the speleothems (Figure 10).

The efflorescence samples were taken to the laboratory where a characterization test was performed. The collected material was found to be fine, dusty and without odor, with white or light yellow color. It was almost insoluble in water and soluble in acid.

This made us think that this efflorescence was the result of the calcium peroxide produced during the cleaning by the interaction of the calcium
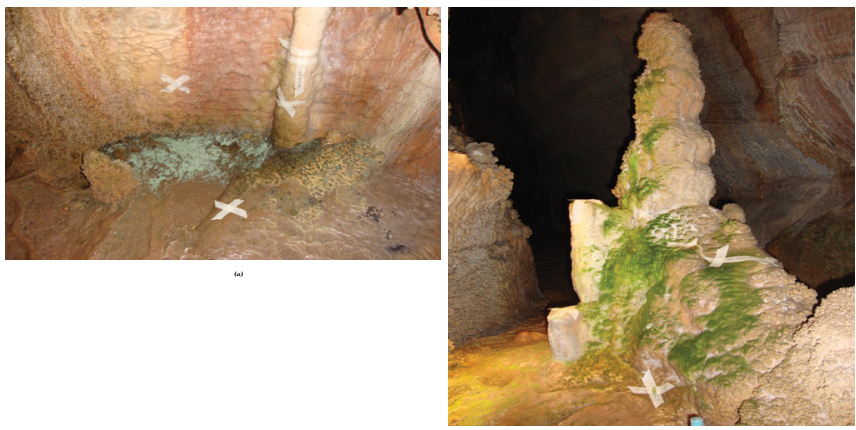

Figure 9) Tests in situ carried out in the caves

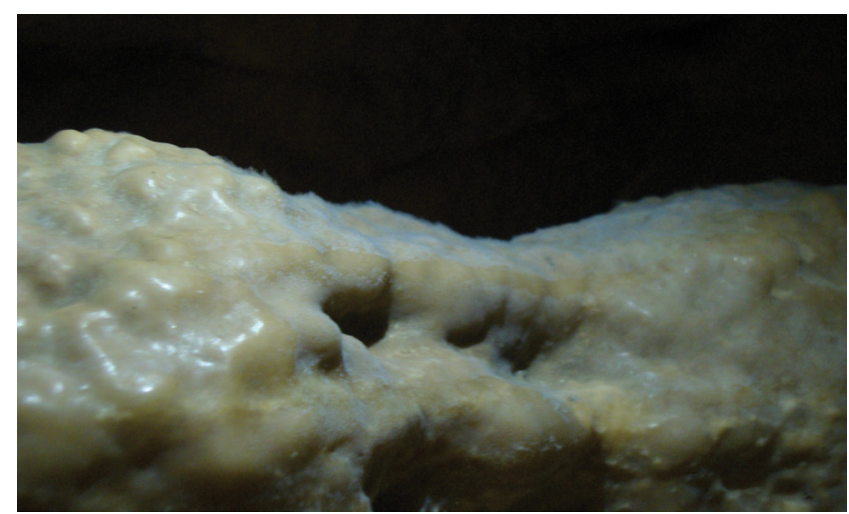

Figure 10) Whitish efflorescence detected in the treated speleothems
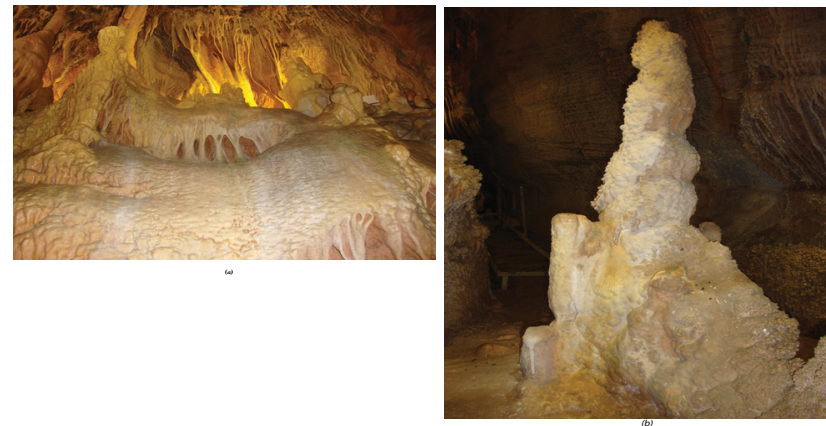

Figure 11) Speleothems once cleaned and after 3 years of the process J Environ Geol Vol 2 No 1 April 2018 carbonate, which is the main component of the speleothems with the $\mathrm{H}_{2} \mathrm{O}_{2}$ used to clean the mat of algae.

$\left[\mathrm{H}_{2} \mathrm{O}_{2}+\mathrm{CaCO}_{3}=\mathrm{H}_{2} \mathrm{CO}_{3}+\mathrm{CaO}_{2}\right]$,

This by-product is a very stable and non-toxic. The spread of calcium peroxide over time would not go beyond the adjustment of the indicated chemical reaction. Therefore, it is necessary take into account the effect of the internal climatic conditions of the cave and the volume of $\mathrm{H}_{2} \mathrm{O}_{2}$ applied in each affected area. When the chemical reaction is adjusted by the effect of time, the formation of $\mathrm{CaO}_{2}$ would stop.

When the results of the project were followed-up during 2015, 2016 and 2017, it was observed that the $\mathrm{CaO}_{2}$ associated efflorescence does not occur again. Speleothems looked clean and with their natural aspect completely recovered (Figures 11A and 11B).

Furthermore, it was observed that the change of lighting from halogen warm light to cold light LED resulted in non-proliferation of new colonies of algae on the caves.

\section{DISCUSSION AND CONCLUSION}

In 2013, the Rehabilitation Project of Ortigosa de Cameros system caves [La Rioja, Spain] was began a with three objectives:

1) The construction of a bioclimatic chamber to stop the advance of the drought at the entrance of the Gruta de La Paz;

2) The replacement of the existing lighting system by one of the cold-light LED type, and

3) Cleaning and regeneration of the speleothems colonized by algae communities.

In the course of this project during 2014, a detailed bibliographical research was carried out and an exhaustive study of the most appropriate methods for the elimination of these algal communities growing in response to artificial lights was developed.

Laboratory tests were performed on samples taken from the caves. Later, the same tests were repeated in the caves. Based on these preliminary tests, hydrogen peroxide presaturated with $15 \%$ and $25 \% \mathrm{CaCO}_{3}$ was chosen for the clean-up of areas colonized by the algae.

Once the results of the In situ tests were verified, all the affected areas were cleaned by following the methodology and parameterization that has been found to be successful in the review of literature.

The final result was very satisfactory. Areas covered by algal communities in forty-two different parts of the cave system were completely removed without causing any damage to the speleothems and without any risk to people and fauna.

During the summer and at the end of 2014, a whitish efflorescence appeared in some speleothems. Upon testing, it was deduced that they are a side-effect of the chemical reaction in which takes place during the cleaning process.

This effect was reviewed periodically during 2015, 2016 and 2017 and it was verified that this phenomenon did not occur again and that it is due to the foregoing. At the end of this project, the speleothems were totally clean and had recovered their natural aspect.

Similarly, it was observed that making a shift from warm halogen light to cold light LED resulted in the non-proliferation of new algal colonies on the caves.

The measures taken to solve the other two mentioned problems i.e., dryness and discoloration of the areas near the entrance of the main caves and the "moonmilk", need to be evaluated at a wider time interval. The time from the initiation of this project until the publication date of this article, is insufficient to observe and assess the results of the measures taken.

This is why we can ensure that the implementation of the scientific method and its application in a project such as the one we are dealing with reflects the importance of experimental science in the preservation of areas of geological interest, as well as the extrapolation of results from the international research to the Geodiversity.

The door is open to continue monitoring and evaluating the natural regeneration of the dry part of the cave, the permanent disappearance of the "green sickness" and the elimination of the microorganisms that destroy the speleothems. Within several years it will be possible to evaluate if the 
measures are taken to solve these environmental problems have had an effect on this system of tourist caves.

\section{ACKNOWLEDGMENTS}

To Directorate General of Culture - Government of the Autonomous Community of La Rioja [Spain] and to the Town Council of Ortigosa de Cameros, that had financed the Project.

To IER - Ministry of Economic Development and Innovation - Government of the Autonomous Community of La Rioja [Spain], for its constant R\&D support and for the publication of my previous works on the subject.

\section{REFERENCES}

1. Colchen M. Geology of Demanda Massif. IGME (Madrid) 1974:436.

2. Ramírez Merino. Geological Map of Spain (1990). Hoja n²41 (Anguiano) I.T.G.E. Madrid. 1990.

3. Goy A. Mesozoic Stratigraphy and Tectonic: Jurasicc. Geology of Spain. $1983 ; 2: 62-79$.

4. Coloma P. Wetlands of environmental interest related to the discharge of groundwater. Basins of the rivers Alhama, Cidacos, Leza-Jubera and Iregua. Zubía Monografic 8. IER - Research Institute. 1996:187-204.

5. Meléndez A. Jurasicc stratigraphy of Anguiano and Munilla geological maps. C.G.S. Madrid. 1989.

6. Calvo Palacios JL. Cameros Basin. IER - Research Institute, Logroño. 1976:297.

7. Osácar MC, Sancho C, Muñoz A, et al. Geochemistry of trace elements in speleothems with seasonal lamination of the caves of Ortigosa de Cameros (La Rioja). Geogaceta, 2013;53:109-12.

8. De Lemus, Subias I, Fernández-nieto C. Mineralogical composition of soils developed on Jurassic limestones of Cameros Basin. Iberian Geology Journal 1990;14:269-81.

9. Esteban Pérez R. Study of the measures taken for the remediation of the environmental impact in the tourist caves of Ortigosa de Cameros (Caves of La Viña and La Paz), La Rioja. Zubía Monografic, IER Research Institute. Government of La Rioja. 2011; 23:221-50.

10. Andrieux C. Contribution to the study of the climate of natural cavities of karstic massifs. Ph.D. Thesis. Université Bordeaux.1969.

11. Schlichting H. Schlichting boundary layer theory. G. Braun, Karlsruhe.1965.

12. Cigna A. The problem of lampenflora in show caves. Proc. Int. Environmental Changes in Karst Areas. I.G.U.-U.I.S. University de Padova, 2010:289-98.

13. Aley T. Control of unwanted plant growth in electrically lighted caves. Caves and Karsts, 1972;14(5): 33-5.

14. Castillo S, Bolivar PY. Bio deterioration of the heritage by cyanobacteria, green algae and diatoms. PH Bulletin Granada.1985;24.

15. Newbould RL. Steam cleaning of Orient Cave, Jenolan Caves, NSW, Jenolan Caves Hist. And preservation Soc, Occ. Pap. No 1. J.C.H. \& P.S. Jenolan Caves. 1974:17.
16. Anon J. The "clean" caves. Panorama. The Journal of Ansett Airlines of Australia 1976;18(6): 1

17. Knutson S. Cleaning calcite formations. Speleograph 10(1):9-10 Reprinted in Mixon, B., 1981. Speleo Digest 1974, National Speleological Society: Alabama, 1974; p. 226.

18. Johnson K. Control of lampenflora at Waitomo Caves, New Zealand. Robinson AC (Ed.), Cave Managements in Australia 111, National Parks and Wildlife Service and Australia Speleological Federation. Sydney 1980:105-22.

19. Caumartin V. Review of the microbiology of underground environments. Bull Nat Speol Soc 1985;25:1-14.

20. Roth J. A remedy for «green sickness». Oregon Caves national Monument. 1995.

21. Lemon L. Algae control and removal from cave formations in National Cave Management Symposium Proceedings. Speleobooks: Albuquerque, New Mexico, 1975: 64-5.

22. http://www.jenolancaves.org.au/

23. Williams P. Report on the conservation of Waitomo Caves. NZ Speleol Bull 1975;5(93):386

24. Rohde K. Cave restoration and cave management. In: Wilson, Lewis (eds.). National Cave management Symposium Proceedings 1978, 1980. Pygmy Dwarf Press: Oregon, 1982:205-7.

25. Faimon J. Environmentally acceptable effect of hydrogen peroxide on cave "lampenflora". Calcite speleothems and limestones. Environmental Pollution, Elsevier Science Ltd. 2003:417-22.

26. Mulec J, Kosi G. Lampenflora algae and methods of growth control. Journal of Cave and Karst Studies. 2009;71(2):109-15.

27. Cigna A. The problem of lampenflora in show caves. Proc. Int Environmental Changes in Karst Areas. I.G.U.-U.I.S. Univ. De Padova, 2010:289-98

28. Hebelka J. Metodology of lampenflora removal in caves accessible for tourists. International Conference of cave lighting, Budapest, 2013:151-7.

29. Esteban Pérez R. Actions for the elimination of the algal mat present in the speleothems in the rehabilitation of the tourist caves of $\mathrm{La} \mathrm{Paz}$ and La Viña in Ortigosa de Cameros - La Rioja. Zubía Sciences Journal, IER Research Institute. Government of La Rioja 2014; 32:7-32.

30. Coloma P. Wetlands of environmental interest related to the discharge of groundwater. Basins of the rivers Alhama, Cidacos, Leza-Jubera and Iregua. Zubía Monografic 8. IER - Research Institute. 1996:187-204.

31. Hebelka J. Metodology of lampenflora removal in caves accessible for tourists. International Conference of cave lighting, Budapest 2013;151-157.

32. Mulec JY, Kosi G. Lampenflora algae and methods of growth control. J Caves Karst Stud 2009;71(2):109-15.

33. Faimon J. Environmentally acceptable effect of hydrogen peroxide on cave "lampenflora". Calcite speleothems and limestones. Environmental Pollution, 2003:417-422.

34. Gazo J. General and inorganic chemistry. Alfa Bratislava, SNTL Praha. 1974 